\title{
A Rare Case Presentation of $\mathrm{HbE} / \boldsymbol{\beta}$ Thalassemia
}

\author{
Anu Singh*, Vijay Kumar, Meetu Singh, Priya Sahu, SadhnaMarwah and Garima Baweja \\ Department of Pathology, ABVIMS \& Dr RML Hospital, New Delhi
}

\section{ABSTRACT}

$\mathrm{HbE} / \beta$ thalassemia(HbE/ $\beta$ thal) genotype accounts for approximately one half of severe $\beta$ thalassemia cases worldwide. The disorder shows marked clinical variability ranging from mild asymptomatic anemia to life threatening disease. Here, we report a case of a 2-year-oldboy from Bihar presenting with severe haemolytic jaundice. Complete haematological profile and Haemoglobin High Performance Liquid Chromatography(HbHPLC) using Biorad version was done of the patient along with the family was done to arrive at the diagnosis of this rare hemoglobinopathy.

Keywords: Thalassemia, Heterozygous pedigree analysis

\section{Introduction}

$\mathrm{HbE} / \beta$ thal genotype accounts for approximately one half of all severe $\beta$ thalassemia cases worldwide. ${ }^{[1]}$ The phenotypic variability of $\mathrm{Hb} E / \beta$-thal and paucity of long-term clinical data, present challenges in providing definitive recommendations for the optimal management of patients. The disorder shows marked clinical variability ranging from mild asymptomatic anemia to life threatening disease. $\mathrm{HbE}$ variant results from a mutation in the beta globin chain where at the $26^{\text {th }}$ position, glutamic acid is replaced by lysine. It tends to elute in A2 window within the retention time ranging from 3.3 to 3.9 min. ${ }^{[2]}$ Genetic factors influencing the severity and clinical diversity of this disorder include type of beta-thalassaemia mutation, co-inheritance of alpha-thalassaemia, $\mathrm{HbA}$ levels, polymorphisms associated with increased production of fetal haemoglobin and co-inheritance with other hemoglobinopathies. ${ }^{[3]}$ Other factors include increased serum erythropoietin levels and its response to age and $\mathrm{HbE}$ levels, malaria infestation, previous splenectomy and other environmental influences. ${ }^{[1]}$

\section{Case Report}

A 2-year-old male, resident of Bihar presented with complaints of abdominal distension, lethargy and irritability for six months. On physical examination, pallor and icterus was noted along with prominent frontal bossing. There was a positive history of passing dark coloured urine for four months. Peripheral smear showed moderate anisopoikilocytosis with predominantly microcytic hypochromic red blood cells with few target cells and polychromatic cells. Complete hemogram along with peripheral smear and biochemical findings revealed features of microcytic hypochromic anaemia with evidence of haemolysis. He had raised bilirubin levels $(4.1 \mathrm{~g} / \mathrm{dl})$, predominantly indirect bilirubin component $(3.8 \mathrm{~g} / \mathrm{dl})$ (Table 1). USG revealed mild splenomegaly with free fluid in peritoneal cavity. Based on clinical history and haematological findings, Hb HPLC of the patient was done which showed increased HbA2 (58.1\%) and $\mathrm{HbF}$ (43.6\%) levels with peak retention time of 1.18 and 3.65 minutes respectively. Following this, Hb HPLC of the parents was done and interpreted as heterozygous $\mathrm{HbA} / \mathrm{E}$ in the father and $\beta$ thalassemia trait in the mother respectively. The probable clinical differentials were $\mathrm{HbD} / \beta^{0}$ thalassemia, $\mathrm{HbE}$ homozygous and thalassemia intermedia. However, after proper family screening, relevant laboratory investigations and HPLC findings of the patient and family, a diagnosis of $\mathrm{HbE} / \AA^{0}$ thal was rendered.

\section{Discussion}

$\mathrm{HbE} / \beta$ thal is a major public health problem in Southeast Asia. Although some progress has been made toward a better understanding of its pathophysiology and clinical management, a great deal remains to be learned still. It is a relatively uncommon and clinically variable condition with symptoms varying from mild/ asymptomatic to severe complications. The pathophysiology of $\mathrm{HbE} / \beta$ thal is attributed to decreased $\mathrm{HbE}$ output and degree of globin chain imbalance along with other modifiers like coinheritance of alpha thalassemia. ${ }^{[1]}$

The highest frequencies are observed in India, Bangladesh and Southeast Asia, particularly in Thailand, Laos and Cambodia with estimated prevalence of around $40 \%$, where it is common for individuals to inherit alleles for both Hemoglobin E ( $\mathrm{Hb}$ E) and beta-thalassaemia. ${ }^{[4]}$ 
Table 1

\begin{tabular}{|c|c|}
\hline Hematological Parameters & Value (Reference Range) \\
\hline $\mathrm{Hb}$ & $6.8(11-14 \mathrm{~g} / \mathrm{dl})$ \\
\hline TLC & $10,700(5,000-15000 / \mathrm{\mu l})$ \\
\hline $\mathrm{DLC}$ & $\mathrm{P}-37 \%, \mathrm{~L}-55 \%, \mathrm{M}-2 \%, \mathrm{E}-6 \%$ \\
\hline Platelet count & $1.8(2-4.9 \mathrm{lakhs} / \mathrm{cumm})$ \\
\hline Reticulocyte count (Corrected) & $5.8(0.5-1.5 \%)$. \\
\hline Biochemical Parameters & Value \\
\hline Total Bilirubin & $4.1(0.2-1.2 \mathrm{mg} / \mathrm{dl})$ \\
\hline Indirect Bilirubin & $3.8(0.2-1.1 \mathrm{mg} / \mathrm{dl})$ \\
\hline SGOT & $65(15-50 \mathrm{U} / \mathrm{L})$ \\
\hline
\end{tabular}

\begin{tabular}{|c|c|c|c|r|}
\hline Peak Name & $\begin{array}{c}\text { Cali.brated } \\
\text { Area 8 }\end{array}$ & Area 8 & $\begin{array}{c}\text { Retention } \\
\text { Time (min) }\end{array}$ & $\begin{array}{c}\text { Peak } \\
\text { Area }\end{array}$ \\
\hline Unknown & --- & 0.2 & 0.54 & 2073 \\
\hline P1 & --- & 0.1 & 0.88 & 1349 \\
\hline F & $43.6^{*}$ & --- & 1.18 & 562789 \\
\hline Ao & --- & 2.2 & 2.30 & 28918 \\
\hline A2 & $58.1^{\star}$ & --- & 3.65 & 716934 \\
\hline \multicolumn{4}{|l}{} \\
\hline \multicolumn{4}{|l}{ Total Area: 1,312,064 }
\end{tabular}

\section{F Concentration $=43.6 * 8$}

A2 Concentration $=58.1 * \%$

*Values outside of expected ranges

Analysis comments:

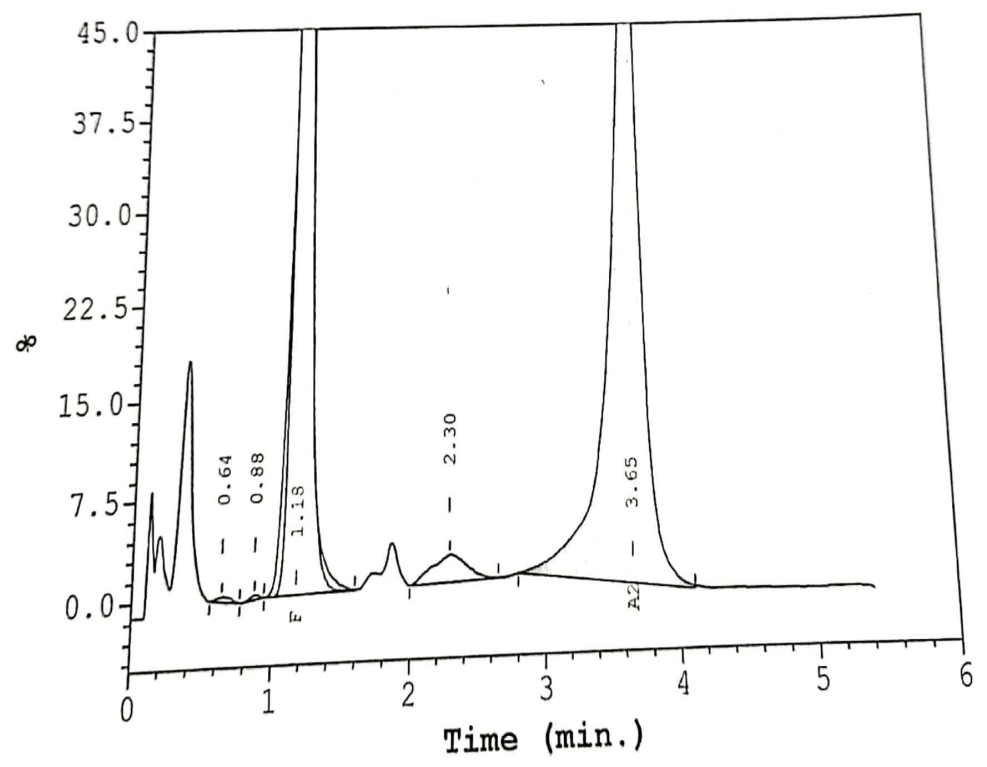

Fig. 1: HPLC graph of the patient. 


\begin{tabular}{|c|c|c|c|r|}
\hline Peak Name & $\begin{array}{c}\text { Calibrated } \\
\text { Area 8 }\end{array}$ & Area 8 & $\begin{array}{c}\text { Retention } \\
\text { Time (min) }\end{array}$ & $\begin{array}{c}\text { Peak } \\
\text { Area }\end{array}$ \\
\hline F & 0.8 & --- & 1.08 & 15721 \\
\hline Unknown & --- & 1.0 & 1.24 & 20721 \\
\hline P2 & --- & 4.1 & 1.36 & 87605 \\
\hline Unknown & --- & 2.5 & 1.75 & 52655 \\
\hline P3 & --- & 3.3 & 1.85 & 70655 \\
\hline Ao & --- & 62.3 & 2.47 & 1334781 \\
\hline A2 & $28.9^{*}$ & --- & 3.65 & 559624 \\
\hline
\end{tabular}

Total Area: 2,141,763

F Concentration $=0.8 \%$

A2 Concentration $=28.9 * 8$

*Values outside of expected ranges

Analysis comments:

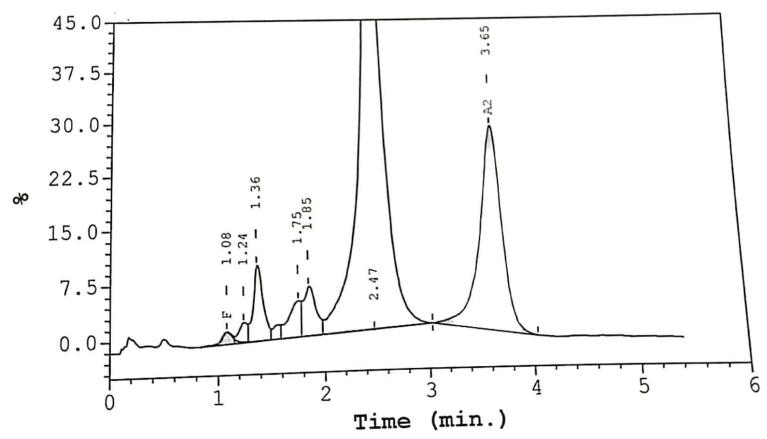

Fig. 2: HPLC graph of the father.

\begin{tabular}{|c|c|c|c|r|}
\hline Peak Name & $\begin{array}{c}\text { Calibrated } \\
\text { Area 8 }\end{array}$ & Area 8 & $\begin{array}{c}\text { Retention } \\
\text { Time (min) }\end{array}$ & \multicolumn{1}{c|}{$\begin{array}{c}\text { Peak } \\
\text { Area }\end{array}$} \\
\hline Unknown & --- & 0.1 & 0.99 & 898 \\
\hline F & 0.9 & --- & 1.09 & 9163 \\
\hline Unknown & --- & 1.1 & 1.25 & 11664 \\
\hline P2 & --- & 3.9 & 1.37 & 42711 \\
\hline P3 & --- & 6.1 & 1.74 & 66619 \\
\hline Ao & --- & 82.2 & 2.48 & 904255 \\
\hline A2 & $6.5^{*}$ & --- & 3.64 & 64978 \\
\hline \multicolumn{4}{|r}{}
\end{tabular}

Total Area: $1,100,288$

F Concentration $=0.98$

A2 Concentration $=6.5 * 8$

*Values outside of expected ranges

Analysis comments:

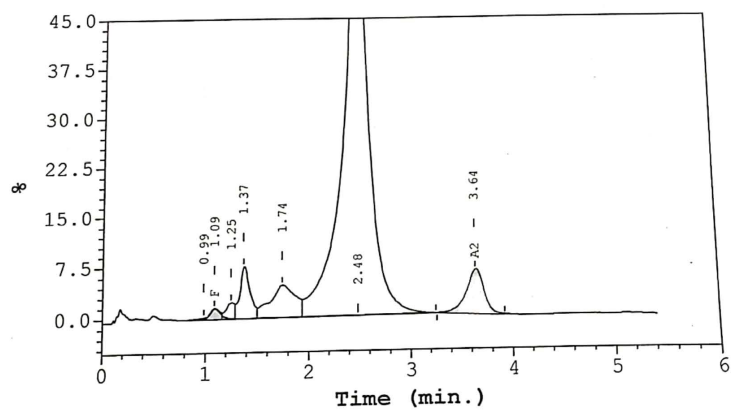

Fig. 3: HPLC graph of the mother.

Annals of Pathology and Laboratory Medicine, Vol. 7, Issue 10, October, 2020 


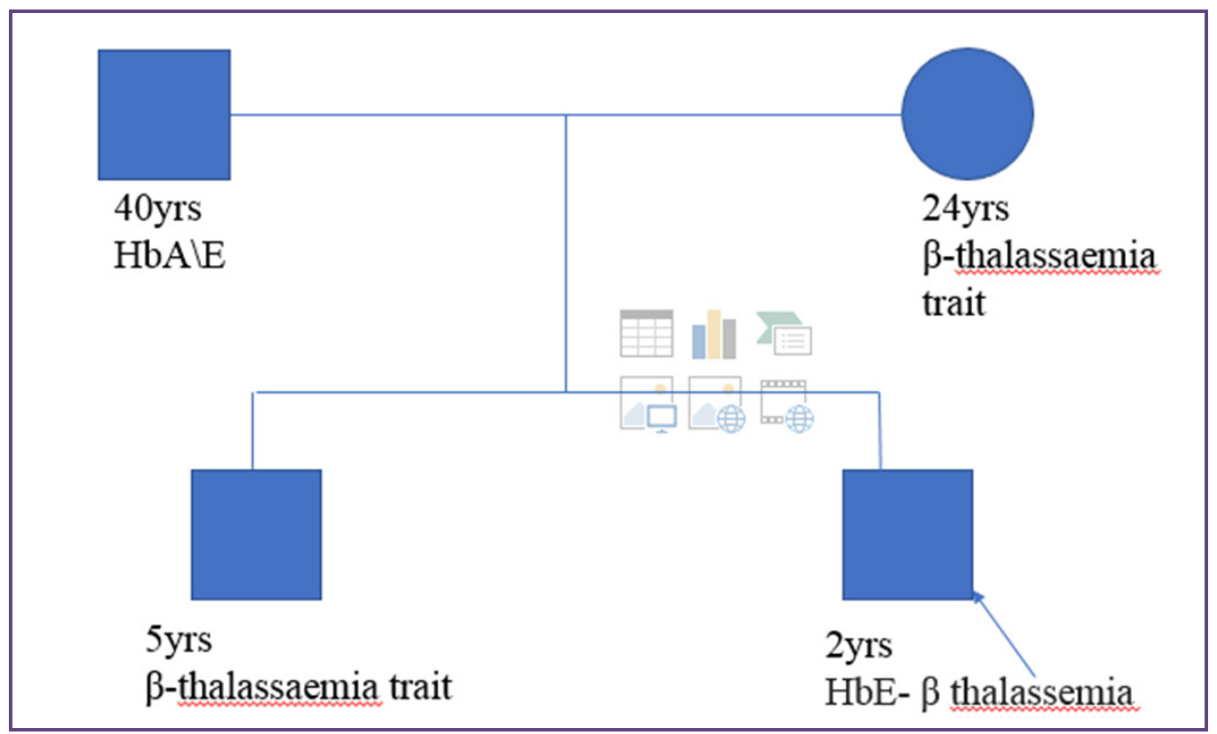

Fig. 4: Pedigree analysis of the patient.

Average $\mathrm{HbE}$ gene frequency in north east India is around $10.9 \%{ }^{[4]}$ In a multicentre study conducted in Mumbai on 65,779 patients, $\mathrm{HbE}$ disease (homozygous $\mathrm{HB} \mathrm{E} / \mathrm{Hb}$ E-beta-thalassemia) accounted for $0.34 \%$ of cases. ${ }^{[2]}$ In a study conducted in eastern India including 119,336 cases, the prevalence of $\mathrm{HbE} / \beta$ thal was $1.16 \%{ }^{[5]}$ Conversely, a study from western India showed a prevalence of $0.2 \%{ }^{\left[{ }^{[6]}\right.}$ A study by Baruah MK et al and Mohanty D et al reported a prevalence of $2.14 \%$ and $0.19 \%$ respectively. ${ }^{[7,8]} \mathrm{A}$ study conducted previously in our institute showed a prevalence of $0.16 \%{ }^{[9]}$

Diagnosis of $\mathrm{HbE}$ can be made through various modalities. Screening tests are osmotic fragility and dichlorophenolindophenol precipitation test. Bone marrow shows features of erythroid hyperplasia, dyserythropoiesis, increased macrophage activity and increased iron storage. Confirmatory tests include Cation exchange HPLC and capillary zone electrophoresis for specificity. Other ancillary techniques include flow cytometry, mutational studies and DNA analysis by multiplex allele specific PCR and amplification refractory mutation system-PCR.

$\mathrm{HbE}$ inheritance may present as homozygous (EE), heterozygous (AE) or compound heterozygous (in association with sickle cell anemia, $\beta$-thalassaemia and other disorders). When $\mathrm{E}$ allele interacts with a $\beta$ thalassemia mutation in the compound heterozygous state, a variable range of haematological parameters is present, with $\mathrm{Hb}$ levels ranging from 3 to $11 \mathrm{~g} / \mathrm{dl}^{\left[{ }^{[3]}\right.}$

The severely affected patients are transfusion dependent and have hepatosplenomegaly, intermittent jaundice, growth retardation, delayed sexual maturation, facial deformity and malposition teeth owing to expansion of bone marrow cavity

At birth, infants with severe $\mathrm{HbE} / \beta$ thal are asymptomatic because $\mathrm{HbF}$ levels are high. $\mathrm{HbF}$ production decreases and is replaced by $\mathrm{HbE}$ at $6-12$ months of age. ${ }^{[1]]}$ Compound heterozygotes for $\mathrm{HbE}$ and B0thalassaemia have haemoglobin $\mathrm{E}$ representing $40-60 \%$ of total haemoglobin; In homozygous $\mathrm{HbE}$, the percentage of $\mathrm{HbE}$ is usually $85-99 \%$. Conversely, haemoglobin $\mathrm{F}$ is $30-60 \%$ in haemoglobin $E / \aleph^{0}$ thalassaemia, whereas, in homozygous haemoglobin $\mathrm{E}$, it is less than $15 \%$. ${ }^{[12]}$ Overall, haemoglobin $\mathrm{F}$ is very variable, from $5 \%$ to $87 \%$. ${ }^{[13]}$ When haemoglobin A is present, it usually constitutes around $10 \%$ of total hemoglobin and HPLC shows haemoglobin $\mathrm{E}, \mathrm{A} 2$ and $\mathrm{F}$ with minimal $\mathrm{HbA}$ levels in the case of $\mathrm{HbE} /$ Bothalassaemia and $\mathrm{Hb} \mathrm{E}, \mathrm{A}, \mathrm{A} 2$ and $\mathrm{F}$ in case of haemoglobin $\mathrm{E} / \mathrm{\beta}+$ thalassemia. ${ }^{[13]}$

$\mathrm{HbE} / \beta$ thal can lead to various complications like hypersplenism, susceptibility to infections, cardiac and pulmonary ailments and thromboembolism. Hemolysis related complications like jaundice, cholecystitis and cholelithiasis has also been reported. Repeated blood transfusions lead to iron overload leading to deposition in various organs and systemic complications like diabetes mellitus. ${ }^{[1]}$ There is an urgent need for the prenatal diagnosis of thalassemia for preventing morbidity and mortality in new born and hence mitigating the burden of hemoglobinopathies in India. The important prerequisite for this disorder is to create awareness on the prevalence of ß-thalassemia in different ethnic groups and in different regions of the country. Education and timely screening 
plays the most important part for the success of prevention programs for the control of thalassemia.

\section{Conclusion}

The remarkable variation and the instability of the clinical phenotype of $\mathrm{HbE}$ beta-thalassaemia suggests that careful tailoring of treatment is required for each patient, and that therapeutic approach should be re-assessed over a period of time. Hence, family screening is important for confirmation, exact characterisation and adequate management. Thus, compound heterozygous $\mathrm{HbE} / \beta$ thal should be considered as an alternative diagnosis in all patients with homozygous $\mathrm{HbE}$ disease who present with severe anemia.

\section{References}

1. Fucharoen S, Weatherall DJ, et al. The hemoglobin E thalassemias. Cold Spring Harb Perspect Med. 2012;2(8):a011734 2012

2. Warghade S, Britto J, Haryan R, Dalvi T, Bendre R, Chheda $\mathrm{P}$, et al. Prevalence of hemoglobin variants and hemoglobinopathies using cation-exchange highperformance liquid chromatography in central reference laboratory of India: A report of 65779 cases. J Lab Physicians 2018;10:73-9.

3. Olivieri NF, Pakbaz Z, Vichinsky E.et al. Hb E/betathalassaemia: A common \& clinically diverse disorder. Indian J Med Res 2011;134:522-31

4. Bharathi KR, Varte V, Singh YA, Devi BK et al. HbE thalassemia in pregnancy. J Med Soc 2015;29:45-6.

5. Mondal SK, Mandal S et al. Prevalence of thalassemia and hemoglobinopathy in eastern India: A 10-year high- performance liquid chromatography study of 119,336 cases. Asian J Transfus Sci. 2016;10:105-110.

6. Bhalodia JN, Oza HV, Modi PJ, Shah AM, Patel KA, Patel HB et al. Study of Hemoglobinopathies in patients of anemia using High Performance Liquid Chromatography (HPLC) in Western India. Natl J Community Med. 2015; 6:35-40.

7. Baruah MK, Saikia M, Baruah A et al. Pattern of hemoglobinopathies and thalassemias in upper Assam region of North Eastern India: high performance liquid chromatography studies in 9000 patients. Indian J Pathol Microbiol. 2014;57:236-43.

8. Mohanty D, Colah RB, Gorakshakar AC, Patel RZ, Master DC, Mahanta $J$ et al. Prevalence of beta-thalassemia and other haemoglobinopathies in six cities in India: a multicentre study. J Community Genet. 2013;4:33-42.

9. Nambiyar, Kaniyappan \& Kumar, Vijay \& Marwah, Sadhna \& Nigam, AbhayShanker. (2017). Analysis of double heterozygous haemoglobinopathies from a tertiary care center in North India. Annals of Pathology and Laboratory Medicine. 4. A610-A614. 10.21276/APALM.1352.

10. Kiran SS, Aithal S, Belagavi CS et al.Hemoglobin E hemoglobinopathy in an adult from Assam with unusual presentation: A Diagnostic dilemma. J Lab Physicians 2016;8:116-9.

11. Thein SL et al. The molecular basis of $\beta$-thalassemia. Cold Spring Harb Perspect Med. 2013;3:a011700.

12. Allen A, Fisher C, Premawardena A, Peto T, Allen S, Arambepola K, Thayalsuthan V, Olivieri N, Weatherall $\mathrm{D}$ et al 2010. Adaptation to anemia in hemoglobin E- $\beta$ thalassemia. Blood 116: 5368-5370.2010

13. Patri B, Sahu AA, Pal S et al. HbE beta - thalassemia: a case report. Int J Health Sci Res. 2016; 6:440-443.

*Corresponding author:

Dr Anu Singh, Senior Resident, Department of Pathology, ABVIMS \& Dr RML Hospital, New Delhi.

Email: anusinghbangalore@gmail.com

Date of Submission : 19/02/2020

Date of Acceptance : 28/08/2020

Financial or other Competing Interests: None.
Date of Publication : 30/10/2020 